\title{
Cyclobutane serine amino acid derivatives as 5-hydroxyproline precursors
}

\section{Marta Pérez-Fernández, Alberto Avenoza,* Jesús H. Busto, Jesús M. Peregrina,* and Fernando Rodríguez}

Departamento de Química, Universidad de La Rioja, Grupo de Síntesis Química de La Rioja, U.A.-C.S.I.C. E-26006 Logroño, Spain E-mail: alberto.avenoza@unirioja.es; jesusmanuel.peregrina@unirioja.es

This article is dedicated to Professor Benito Alcaide on the occasion of his $60^{\text {th }}$ birthday

\begin{abstract}
The synthesis of the 5-hydroxyproline derivatives $\mathbf{3 a}$ and $\mathbf{3 b}$ using cyclobutane serine analogs $\mathbf{1}$ and $\mathbf{2}$ as starting materials is reported. This process occurs with moderate cis/trans selectivity. A mechanism for this reaction is also proposed. Cyclobutane serine analog $\mathbf{1}$ was tested in tandem Michael and Wittig-like reactions, providing some evidence of the mechanism proposed.
\end{abstract}

Keywords: 5-Hydroxyproline, cyclobutane derivatives, Michael addition, Wittig reaction

\section{Introduction}

3-Hydroxyproline and 4-hydroxyproline are basic components of collagen, the most abundant protein in vertebrates. ${ }^{1}$ Both of these proline derivatives are non-proteinogenic amino acids that play an important role in the stabilization of the collagen triple helix. ${ }^{2}$ As far as 5-hydroxyproline is concerned, its concentration in injured tissues is a parameter associated with their wound healing capacity. ${ }^{3}$ In addition, 5-hydroxyprolines have been used as building blocks for the preparation of other optically active proline derivatives ${ }^{4}$ and can be considered as versatile precursors for the synthesis of conformationally restricted peptidomimetics. ${ }^{5}$

Bearing all that in mind, different protocols have been developed to obtain these 5hydroxylated compounds. The main methodology consists of the reduction of the $\gamma$-lactamic carbonyl group of conveniently protected pyroglutamic acid derivatives as a key step of the synthesis. $^{5,6}$ A wide variety of 5-hydroxyprolines have been prepared according to this methodology (Scheme 1a). It has also been reported that the $N$-Boc-protected aldehyde derived from glutamic acid is spontaneously transformed into the corresponding 5-hydroxyproline tert- 
butyl ester. ${ }^{7}$ On this basis, Johannesson et al. achieved the synthesis of the Fmoc-protected diastereomeric mixture depicted in Scheme $1 \mathrm{~b}$ from commercially available Boc-Glu-O ${ }^{t} \mathrm{Bu} .{ }^{8}$

Furthermore, $\alpha, \alpha$-disubstituted 5-hydroxyprolines have been prepared in good enantiomeric excess by organocatalytic asymmetric synthesis. It has recently been described that the reaction between $\alpha, \beta$-unsaturated aldehydes and either 2-acylaminomalonates ${ }^{9}$ or oxazolones ${ }^{10}$ leads to the type of hydroxyprolines displayed in Scheme $1 \mathrm{c}$ in good yields. Finally, as an example of the synthesis of 5-alkoxyprolines, the preparation of the 5-methoxyproline presented in Scheme 1d was accomplished by a less common strategy, which involves the regioselective electrochemical oxidation of the corresponding bicyclic precursor. ${ }^{5 c, 11}$

a)<smiles>[R]C1CC(C=[R])N([R])C1[O]</smiles>

b)<smiles>O=C(O)[C@@H]1CC[C@@H](O)N1</smiles>

c)

d)<smiles>COC(=O)C1C[C@H]2CCCC[C@]2(OC(C)=O)N1C(C)=O</smiles>

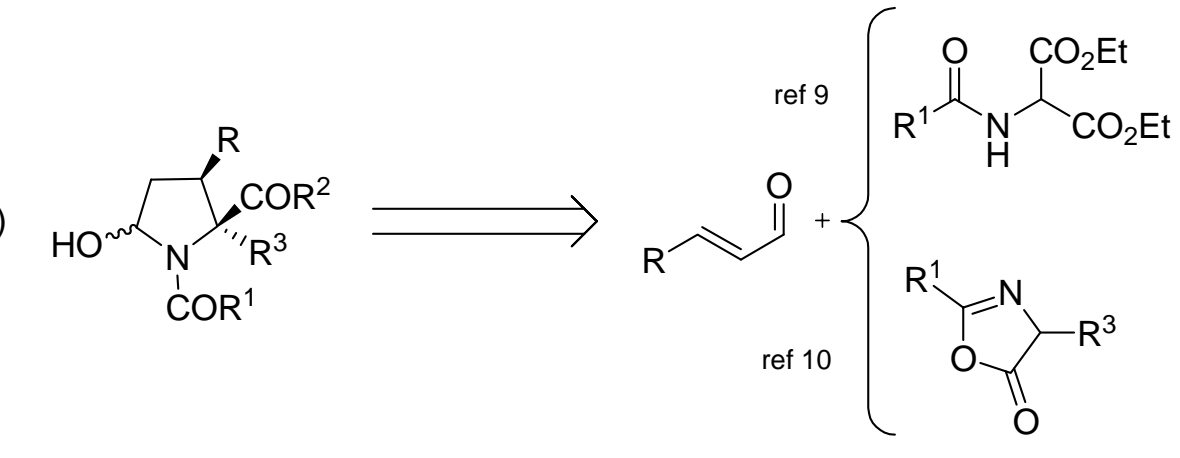

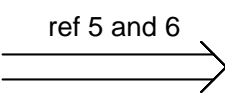

ref 8

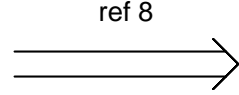

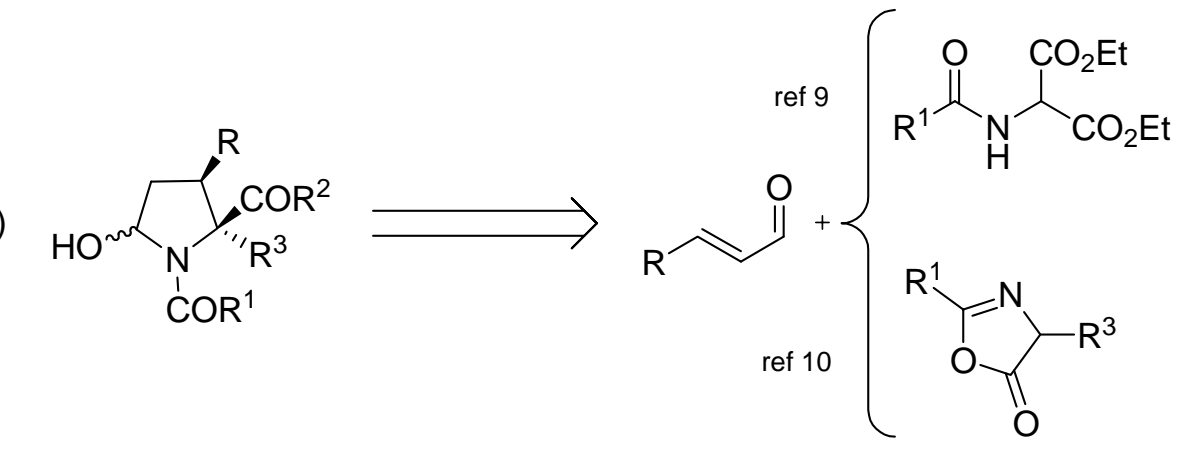

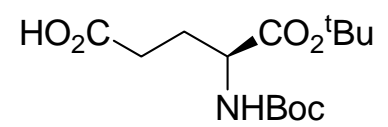
Boc-Glu-O'Bu

Pyroglutamic acid derivatives

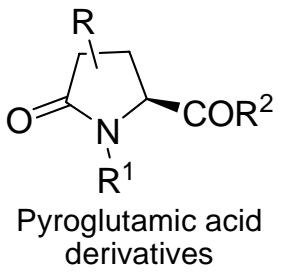

HBoc

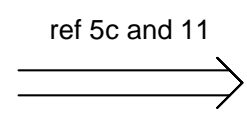

\section{Scheme 1}

In contrast, cyclobutane compounds have received great attention in the last few years, ${ }^{12}$ since they are important building blocks for the preparation of natural products. Particularly, the interest in the synthesis of new cyclobutane amino acids ${ }^{13}$ has increased after the discovery of potent naturally occurring neurotransmitters with the same substructure. ${ }^{14}$ In this context, our research group has reported some examples of these types of substrates. ${ }^{15}$ In all cases, the fourmember ring formation was based on the formal [2+2] cycloaddition between 
acylaminoacrylates and different donor olefins. Thus, the reaction between 2(acylamino)acrylates and ketene diethyl acetal provides the cyclobutane skeleton following a Michael-Dieckmann-type mechanism, ${ }^{12 c, 15 a, b, d, 16}$ whereas the use of monosubstituted donor alkenes with the same acrylate acceptors requires activation by aluminium Lewis Acids, ${ }^{15 c, e}$ leading to the products via stereoselective Michael-aldol processes ${ }^{15 c, e}$ (Scheme 2a). It is worth mentioning that a number of serine ( $\mathrm{c}_{4} \mathrm{Ser}$ ), cysteine ( $\left.\mathrm{c}_{4} \mathrm{Cys}\right)$, glycine ( $\mathrm{c}_{4}-\alpha$-vinylGly) and homoalanine (c4homoAla) analogs were obtained by this methodology. Among the $\mathrm{c}_{4} \mathrm{Ser}$ derivatives, compounds $\mathbf{1}$ and $\mathbf{2}$ displayed in Scheme $2 \mathrm{~b}$ have been used as starting materials for the work described herein.

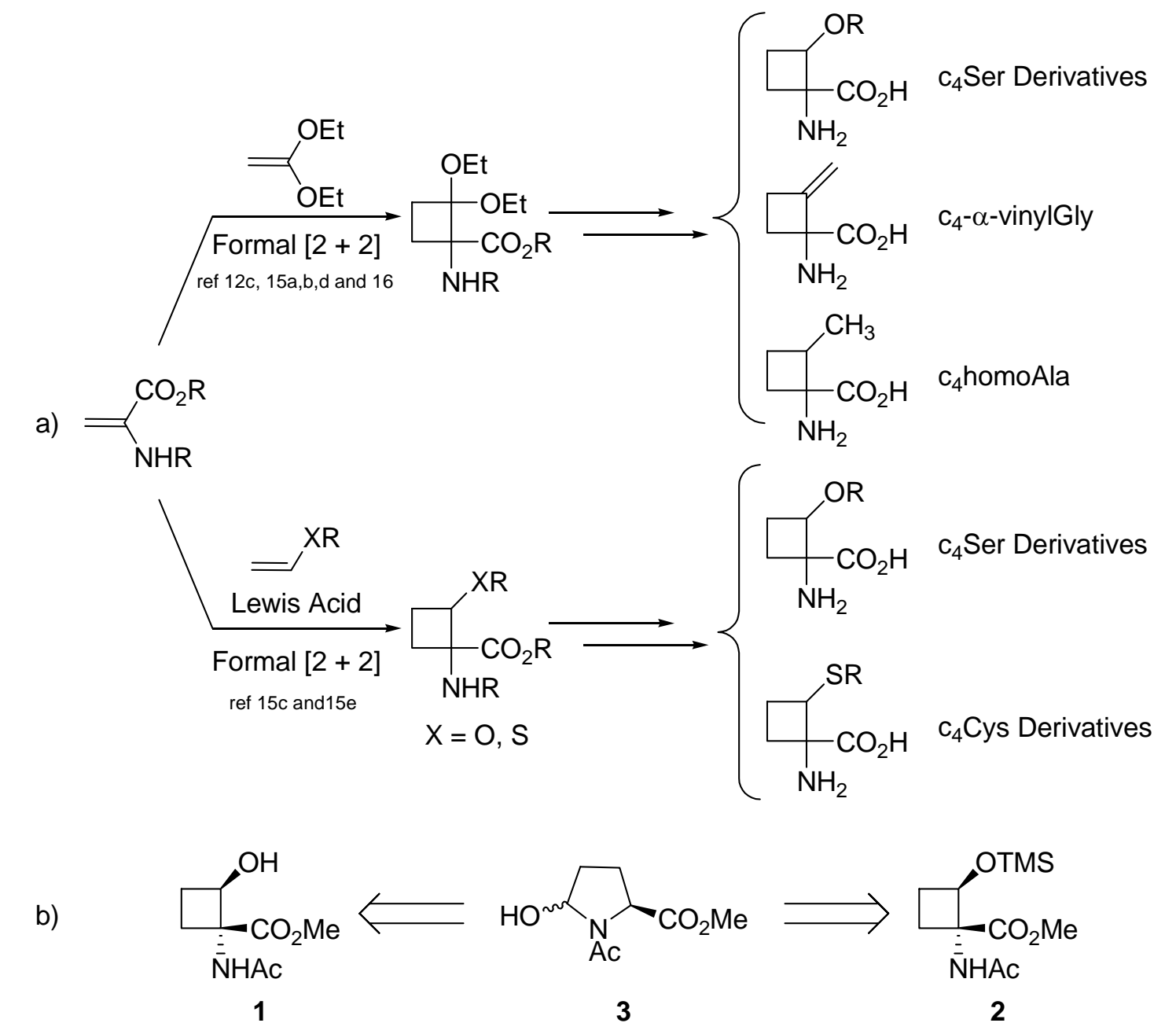

\section{Scheme 2}

In this paper we report the simple preparation of the 5-hydroxyprolines 3 using the serine cyclobutane derivatives $\mathbf{1}$ and $\mathbf{2}$ as starting materials (Scheme 2b). Moreover, as a possible synthetic application, the reactivity of compound $\mathbf{1}$ was tested in tandem Michael and Wittig-like reactions. 


\section{Results and Discussion}

\section{Synthesis of 5-hydroxyproline derivatives}

Cyclobutane alcohol $\mathbf{1}$ was prepared in good yield by conventional hydrogenolysis of the benzyloxy derivative 4 in ethyl acetate using 10\% Pd-C as a catalyst (Scheme 3). The synthesis of compound 4 had been previously described by our group and involved the formal [2 +2$]$ cycloaddition between methyl 2-acetamidoacrylate and benzyl vinyl ether assisted by MABR as Lewis Acid. ${ }^{15 c}$

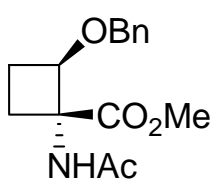

4
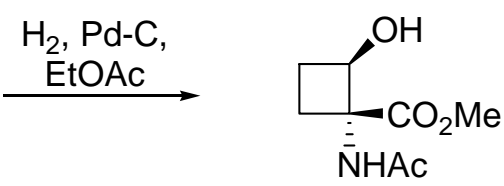

1

\section{Scheme 3}

Similarly, as stated above, the diethyl acetal analog 5 had also been synthesized by our group by formal [2 + 2] cycloaddition between methyl 2-acetamidoacrylate and ketene diethyl acetal. $^{12 c, 15 a, b, d, 16}$ This compound proved to be quite unstable when subjected to a number of test reactions, resulting in formation of the glutamic acid derivative $\mathbf{6}$ by ring opening (Scheme 4a). ${ }^{15 d}$ Bearing that in mind, and given the conformational rigidity of the cyclobutane skeleton, it was decided to test the stability and/or reactivity of these types of systems under different conditions. Thus, compound $\mathbf{1}$ was treated with one equivalent of sodium hydride in THF at room temperature, leading to a mixture of the 5-hydroxyprolines $\mathbf{3 a}$ and $\mathbf{3 b}$ in a 68/32 ratio (Scheme 4b). Assignment of the signals corresponding to $\mathbf{3 a}$ (cis, red in Figure 1) and $\mathbf{3 b}$ (trans, blue in Figure 1) was carried out by selective 1D ROESY experiments performed over a sample purified by silica gel column chromatography, whereas the cis/trans ratio was determined by integration of the ${ }^{1} \mathrm{H}$ NMR signals identified for each 5-hydroxyproline.

a)

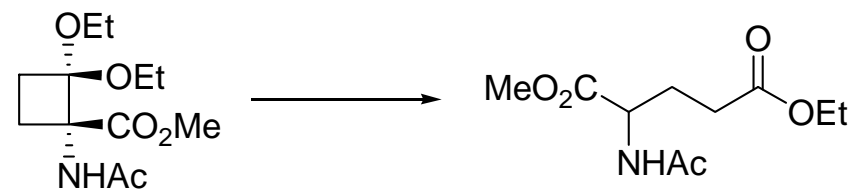

5

6

b)

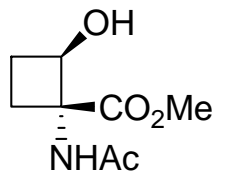

1

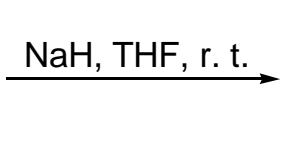<smiles>[CH]N1[C@H](O)CC[C@@H]1C(C)=O</smiles>

3a<smiles>CC(=O)[C@H]1CC[C@@H](O)N1C</smiles>

$3 b$

\section{Scheme 4}




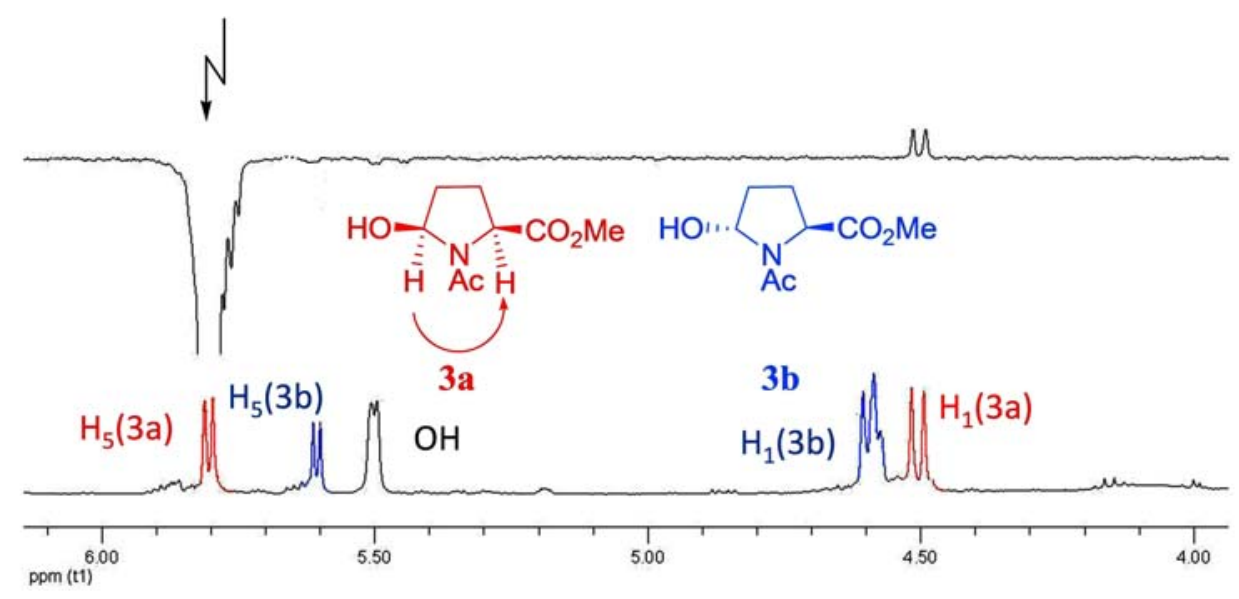

Figure 1. Example of a selective 1D ROESY experiment at a mixing time of $800 \mathrm{~ms}$ performed over a sample containing a mixture of $\mathbf{3 a}$ and $\mathbf{3 b}$.

In order to explore this reaction in more detail and to understand the influence of the reaction conditions in the cis/trans (3a/3b) selectivity, compound $\mathbf{1}$ was subjected to treatment with other bases at different temperatures (Table 1). As can be deduced from Table 1, temperature does not seem to make any difference in the cis/trans selectivity, since all the results obtained for ${ }^{\mathrm{t}} \mathrm{BuOK}$ are within a $2 \%$ range. Nevertheless, more important variations are observed depending on the base selected, with the $\mathbf{3 a} / \mathbf{3 b}$ ratio ranging from 68/32 (for $\mathrm{NaH}$ ) to $45 / 55$ (for $\mathrm{Cs}_{2} \mathrm{CO}_{3}$ ). It is important to note that in most cases, the cis derivative is the favored stereoisomer. Only treatment with cesium carbonate leads to the trans isomer as the major product.

Table 1. Reaction conditions and cis/trans selectivity obtained in the synthesis of 5hydroxyprolines $\mathbf{3 a}$ and $\mathbf{3 b}$ starting from compound $\mathbf{1}$

\begin{tabular}{ccc}
\hline Base & Temperature & 3a/3b ratio \\
\hline $\mathrm{NaH}^{\mathrm{a}}$ & $25^{\circ} \mathrm{C}$ & $68 / 32$ \\
$\mathrm{DIEA}^{\mathrm{a}}$ & $25^{\circ} \mathrm{C}$ & $60 / 40$ \\
${ }^{\mathrm{t}} \mathrm{BuOK}^{\mathrm{b}}$ & $-10^{\circ} \mathrm{C}$ & $62 / 38$ \\
${ }^{\mathrm{t}} \mathrm{BuOK}^{\mathrm{b}}$ & $40^{\circ} \mathrm{C}$ & $61 / 39$ \\
${ }^{ } \mathrm{BuOK}^{\mathrm{b}}$ & $25^{\circ} \mathrm{C}$ & $60 / 40$ \\
$\mathrm{LiOH}^{\mathrm{b}}$ & $25^{\circ} \mathrm{C}$ & $56 / 44$ \\
$\mathrm{DBU}^{\mathrm{b}}$ & $25^{\circ} \mathrm{C}$ & $55 / 45$ \\
$\mathrm{NH}_{4} \mathrm{OH}^{\mathrm{b}}$ & $25^{\circ} \mathrm{C}$ & $53 / 47$ \\
$\mathrm{Cs}_{2} \mathrm{CO}_{3}{ }^{\mathrm{b}}$ & $25^{\circ} \mathrm{C}$ & $45 / 55$ \\
$\mathrm{AcOH} / \mathrm{AcO}^{-} \mathrm{Buffer}$ & $25^{\circ} \mathrm{C}$ & $69 / 31$ \\
\hline
\end{tabular}

a 1.0 equivalents of base used;

${ }^{\mathrm{b}} 0.1$ equivalents of base used; 
A proposed mechanism for this reaction in basic media is depicted in Scheme 5. First, a retroaldolic process takes place after removal of the hydroxyl proton by the corresponding base. The aldehyde formation along with the cyclobutane ring opening leads to a tertiary carbanion. Secondly, a series of acid-base equilibriums results in an amide anion formation. Finally, the amide nucleophilic attack onto the aldehyde carbonyl group gives the 5-hydroxyproline mixture 3a/3b after protonation. The electron-withdrawing character of the carboxylate group could be the driving force of the reaction, since it is capable of stabilizing the carbanion formed in the retroaldolic process.

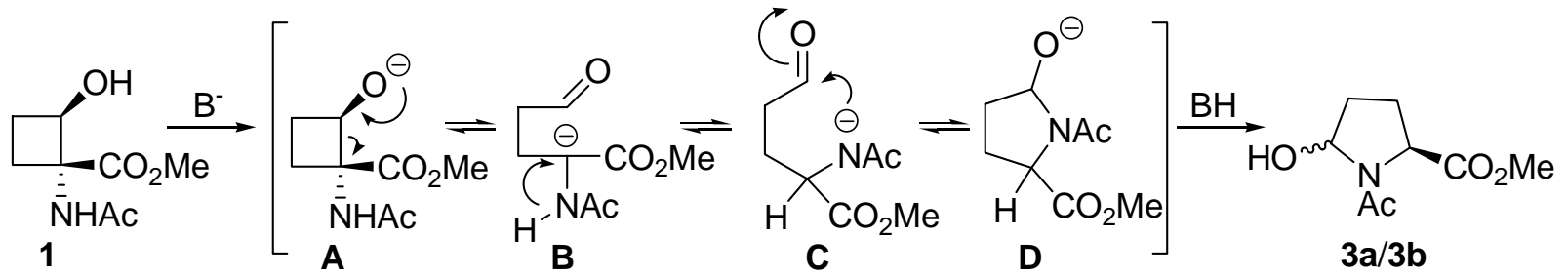

\section{Scheme 5}

Likewise, ring opening and further 5-hydroxyproline formation was observed when compound 1 was treated in acidic conditions (acetic acid/sodium acetate buffer). Remarkably, the cis/trans selectivity obtained (69/31, Table 1), was the best of the series.

An alternative approach to accomplishing the synthesis of the 5-hydroxyprolines $\mathbf{3 a}$ and $\mathbf{3 b}$ might be the in situ generation of the same alkoxy anion displayed in Scheme 5 using a different starting material. Consequently, deprotection of alkyl silyloxy derivatives with fluoride anions appeared to be a valid possibility. In this context, our group has previously reported the synthesis of the trimethylsilyloxy derivative 2 by the usual [2+2] cycloaddition methodology. ${ }^{15 c}$ This compound was selected as the starting material for the reaction with different fluorides in THF aiming at the preparation of substrates $\mathbf{3 a}$ and $\mathbf{3} \mathbf{b}$. As expected, and as in the case of the treatment of compound $\mathbf{1}$ with different bases, the hydroxyprolines $\mathbf{3 a}$ and $\mathbf{3 b}$ were the isolated products (Scheme 6). The results obtained under the reaction conditions tested are gathered in Table 2.

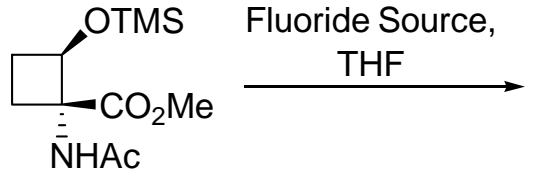

2

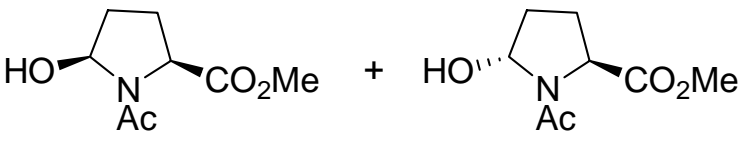

$3 a$ 3b

\section{Scheme 6}


Table 2. Cis/trans selectivity obtained in the synthesis of 5-hydroxyprolines $3 \mathbf{a}$ and $\mathbf{3 b}$ starting from compound 2

\begin{tabular}{ccc}
\hline Fluoride Source & Temperature & 3a/3b ratio \\
\hline TBAF & $0{ }^{\circ} \mathrm{C}$ & $59 / 41$ \\
TBAF & $25^{\circ} \mathrm{C}$ & $30 / 70$ \\
HF.Py & $25^{\circ} \mathrm{C}$ & $55 / 45$ \\
\hline
\end{tabular}

Unlike the case of treatment of compound 1 with different bases, the temperature has an important effect on the cis/trans selectivity. Thus, when TBAF is used as the fluoride source at $0{ }^{\circ} \mathrm{C}$, the cis isomer is the major product, whereas at $25^{\circ} \mathrm{C}$, the cis/trans selectivity is in favor of the latter one. Similarly, at $25^{\circ} \mathrm{C}$, the exchange of TBAF by HF.Py provokes a change in the 3a/3b selectivity. Taking these results into account, the stereochemistry of this process appears to be reasonably sensitive to the reaction conditions.

\section{Synthetic applications: Michael and Wittig-like reactions}

Among the four intermediates proposed in the mechanism depicted in Scheme 5, two of them contain the aldehyde group (B and $\mathbf{C}$ ), which makes them suitable for Wittig-like reactions, whereas the other ones, depending on their stability, could be good candidates for use in the reaction with different electrophiles, since they are oxygenated nucleophiles (A and $\mathbf{D}$ ). Bearing in mind that these intermediates are generated in situ from compound 1, identification and/or isolation of the products expected from such intermediates in either Wittig-like reactions or Michael-like additions, using compound $\mathbf{1}$ as starting material, would provide some evidence of the mechanism proposed, and would make this cyclobutane containing analog a versatile building block for the synthesis of more complex molecules.

When compound 1 was treated with different Michael acceptors such as acrylonitrile, acrolein or methyl acrylate in the presence of ${ }^{\mathrm{t}} \mathrm{BuOK}$, only methyl acrylate led to formation of products different from the 5-hydroxyprolines $\mathbf{3 a}$ and $\mathbf{3 b}$. In this case, although compounds $\mathbf{3 a}$ and $\mathbf{3 b}$ were also the main products, a mixture containing the two diastereomers of the diester $\mathbf{7}$ was isolated in a $14 \%$ yield (Scheme $7 \mathrm{a}$ ). As might be expected, these side products were the result of the Michael addition of the last intermediate (D) proposed in Scheme 5 to methyl acrylate. The low yield obtained could be explained by a fast final protonation step to form the 5hydroxyproline derivatives, which would prevent the Michael addition to the $\alpha, \beta$-unsaturated systems used. 
a)

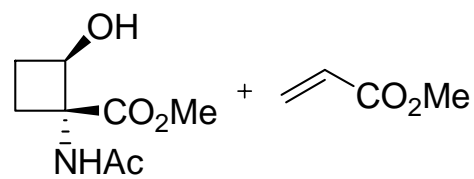

1

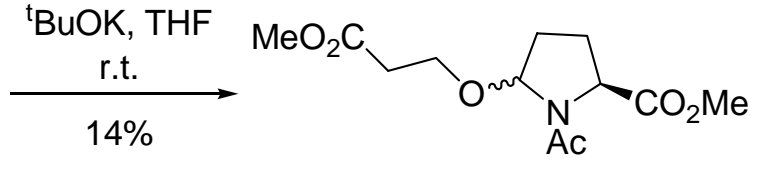

7

b)

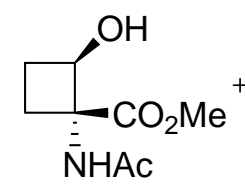

1<smiles>COC(=O)CP(=O)(OC)OC</smiles>

$69 \%$
8

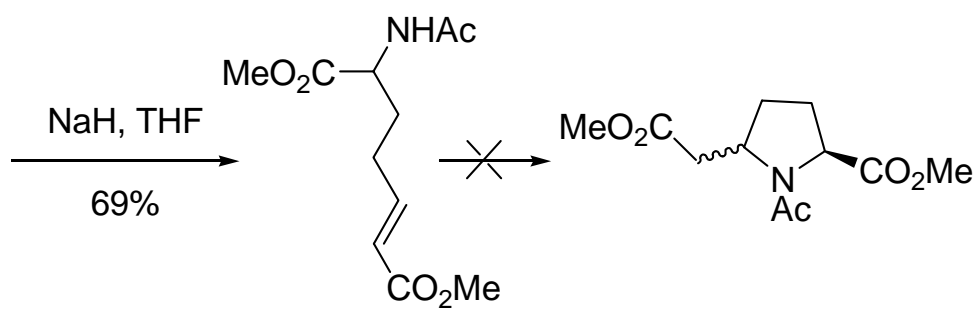

9

\section{Scheme 7}

Regarding Wittig-like reactions, different phosphorus derivatives can be used in these types of processes. ${ }^{17}$ Among these derivatives, trimethyl phosphonoacetate was selected to carry out the reaction with compound $\mathbf{1}$ in the presence of $\mathrm{NaH}$. Thus, when one equivalent of compound $\mathbf{1}$ was reacted with two equivalents of the phosphorus derivative and two equivalents of $\mathrm{NaH}$, the expected $\alpha, \beta$-unsaturated diester 8 was obtained in a $69 \%$ yield (Scheme $7 \mathrm{~b}$ ). Conversely to what is described in the literature, ${ }^{18}$ the Wittig-product 8 did not undergo ring closure by intramolecular Michael addition to form the pyrrolidine mixture $\mathbf{9}$.

After these preliminary results, it can be said that the use of compound $\mathbf{1}$ as starting material in tandem Michael and Wittig-like reactions has provided some evidence of the mechanism proposed in Scheme 5, proving its potential as a building block for the synthesis of more complex molecules.

\section{Conclusions}

In this work a new and simple methodology for the preparation of the 5-hydroxyprolines 3a and $\mathbf{3 b}$ has been developed. This methodology relies on the use of cyclobutane serine analogs $\mathbf{1}$ and $\mathbf{2}$ as starting materials. Treatment of derivative $\mathbf{1}$ in basic media or fluoride removal of the trimethylsilyloxy group present in compound $\mathbf{2}$ with different fluoride sources led to the 5hydroxyprolines $\mathbf{3 a}$ and $\mathbf{3 b}$ in good yield and moderate selectivity.

In addition, supporting evidence of the mechanism proposed was provided by the use of compound $\mathbf{1}$ in tandem Michael and Wittig-like reactions. 


\section{Experimental Section}

General Procedures. Solvents were purified according to standard procedures. Analytical TLC was performed using Polychrom SI $\mathrm{F}_{254}$ plates. Column chromatography was performed using silica gel 60 (230-400 mesh). ${ }^{1} \mathrm{H}$ and ${ }^{13} \mathrm{C}$ NMR spectra were recorded on a Bruker ARX-300 spectrometer using $\mathrm{CDCl}_{3}$ with TMS as internal reference. Chemical shifts are reported in parts per million on the $\delta$ scale and coupling constants are given in Hz. Assignment of all separate signals in the ${ }^{1} \mathrm{H}$ NMR spectra was made on the basis of coupling constants, ge-COSY, geHSQC and 1D ROESY experiments on a Bruker AVANCE 400 spectrometer. These experiments were processed with Mestre Nova software (Mestrelab Research, Spain). Mass spectrometry data were obtained with a Bruker MicrOTOF spectrometer using ElectrosprayIonization (ESI). Microanalyses were carried out in the Department of Chemistry at the Universidad de La Rioja on a CE Instruments EA-1110 analyser and are in good agreement with the calculated values.

$(1 R, 2 R)$ - and (1S,2S)-Methyl 1-acetamido-2-hydroxycyclobutanecarboxylate (1). A solution of compound 4 (440 mg, $1.59 \mathrm{mmol})$ in EtOAc (10 mL) was hydrogenated at room temperature and atmospheric pressure in the presence of $40 \mathrm{mg}$ of $10 \% \mathrm{Pd}-\mathrm{C}$. After complete disappearance of the starting material, the reaction mixture was filtered through a pad of Celite to remove the catalyst and the filter cake was rinsed with $50 \mathrm{~mL}$ of EtOAc. The solvent was evaporated in vacuo to give a residue that was purified by silica gel column cromathography eluting with $\mathrm{MeOH} / \mathrm{EtOAc}(1: 9)$ to afford compound 1 as a colorless oil (282mg, 95\%). ${ }^{1} \mathrm{H}-\mathrm{NMR}\left(\mathrm{CDCl}_{3}\right): \delta$ 1.25-1.82 (m, $1 \mathrm{H}, \mathrm{H}_{4}$ ), 2.00 (s, 3H, $\mathrm{CH}_{3} \mathrm{CO}$ ), 2.18-2.31 (m, $\left.2 \mathrm{H}, 2 \mathrm{H}_{3}\right), 2.43-2.47$ (m, $\left.1 \mathrm{H}, \mathrm{H}_{4}\right)$, 3.79 (s, 3H, $\mathrm{CH}_{3} \mathrm{O}$ ), 3.97 (br s, $1 \mathrm{H}, \mathrm{OH}$ ), 4.44 (t, $1 \mathrm{H}, J=8.8 \mathrm{~Hz}, \mathrm{H}_{2}$ ), 6.80 (br s, $\left.1 \mathrm{H}, \mathrm{NH}\right) .{ }^{13} \mathrm{C}-$ NMR $\left(\mathrm{CDCl}_{3}\right)$ : $23.0\left(\mathrm{CH}_{3} \mathrm{CO}\right), 23.3\left(\mathrm{C}_{4}\right), 26.2\left(\mathrm{C}_{3}\right), 52.5\left(\mathrm{CH}_{3} \mathrm{O}\right), 66.2\left(\mathrm{C}_{1}\right), 72.5\left(\mathrm{C}_{2}\right), 170.7$ (COO), $172.0(\mathrm{CON})$; ESI+ (m/z): $210.0(\mathrm{M}+\mathrm{Na})^{+}$; Anal. Calcd. for $\mathrm{C}_{8} \mathrm{H}_{13} \mathrm{NO}_{4}(\%): \mathrm{C}, 51.33 ; \mathrm{H}$, 7.00; N, 7.48. Found: C, 51.22; H, 7.05; N, 7.51.

\section{General procedure for the preparation of methyl 1-acetyl-5-hydroxypyrrolidine-2- carboxylates $3 a$ and $3 b$}

Method A. Compound 1 (50 mg, $0.27 \mathrm{mmol}$ ) was dissolved in dry THF (5 mL) and treated with the corresponding base (1.0 equiv for $\mathrm{NaH}$ and DIEA and 0.1 equiv for the rest of bases). After appropriate reaction time, the reaction was stopped with $0.1 \mathrm{~N} \mathrm{HCl}(1 \mathrm{~mL})$, diluted with EtOAc $(10 \mathrm{~mL})$, and washed with $\mathrm{H}_{2} \mathrm{O}(10 \mathrm{~mL})$. The organic phase was dried over anhydrous $\mathrm{Na}_{2} \mathrm{SO}_{4}$, filtered, and concentrated in vacuo to give the mixture of 5-hydroxyprolines $3 \mathbf{a}$ and $\mathbf{3 b}$. (Yield ranging from 70 to $85 \%$ ).

Method B. Method B. Compound 2 (70 mg, $0.27 \mathrm{mmol}$ ) was dissolved in dry THF (5 mL) and treated with either TBAF or HF.Py (1.1 equiv). The reaction mixture was stirred for the appropriate reaction time, diluted with EtOAc $(10 \mathrm{~mL})$, and washed with $\mathrm{H}_{2} \mathrm{O}(5 \mathrm{~mL})$. The organic layer was dried over anhydrous $\mathrm{Na}_{2} \mathrm{SO}_{4}$, filtered, and concentrated in vacuo. The residue 
obtained was purified by silica gel column chromatography eluting with $\mathrm{MeOH} / \mathrm{EtOAc}$ (1:9) to give a mixture of $\mathbf{3 a}$ and $\mathbf{3 b}$. (Yield ranging from 60 to $75 \%) .{ }^{1} \mathrm{H}-\mathrm{NMR}\left(\mathrm{CDCl}_{3}\right): \delta 1.88-2.14(\mathrm{~m}$, $8 \mathrm{H}, \mathrm{CH}_{3} \mathrm{CO}, \mathrm{CH}_{2}, \mathrm{CH}_{2}, \mathrm{CH}_{2}$ ), 2.16-2.30 (m, $4 \mathrm{H}, \mathrm{CH}_{3} \mathrm{CO}, \mathrm{CH}_{2}$ ), 2.37-2.47 (m, $1 \mathrm{H}, \mathrm{CH}_{2 \mathrm{~b}}$ ), 2.54$2.64\left(\mathrm{~m}, 1 \mathrm{H}, \mathrm{CH}_{2 \mathrm{a}}\right.$ ), 3.71 (s, $3 \mathrm{H}, \mathrm{CH}_{3} \mathrm{O}_{\mathrm{b}}$ ), 3.77 (s, $\left.3 \mathrm{H}, \mathrm{CH}_{3} \mathrm{O}_{\mathrm{a}}\right), 4.45$ (d, $1 \mathrm{H}, J=8.8 \mathrm{~Hz}, \mathrm{CH}_{\mathrm{a}}$ ), 4.56 (d, $1 \mathrm{H}, J=8.8 \mathrm{~Hz}, \mathrm{CH}_{\mathrm{b}}$ ), 5.57 (d, $\left.1 \mathrm{H}, J=5.1 \mathrm{~Hz}, \mathrm{CH}_{\mathrm{b}}\right), 5.76$ (d, $1 \mathrm{H}, J=5.8 \mathrm{~Hz}, \mathrm{CH}_{\mathrm{a}}$ ); ${ }^{13} \mathrm{C}-$ NMR ( $\left(\mathrm{CDCl}_{3}\right)$ : 21.6, $21.8\left(\mathrm{CH}_{3} \mathrm{CO}\right)$, 25.9, $26.7\left(\mathrm{CH}_{2}\right), 28.8,30.3\left(\mathrm{CH}_{2}\right), 52.3,52.8\left(\mathrm{CH}_{3} \mathrm{O}\right)$, 58.4, $60.3(\mathrm{CH}), 82.1$, $83.1(\mathrm{CH}), 170.5,170.6,172.2,172.3(\mathrm{CO})$; ESI+ (m/z): $188.2(\mathrm{M}+\mathrm{H})^{+}$; Anal. Calcd. for $\mathrm{C}_{8} \mathrm{H}_{13} \mathrm{NO}_{4}$ (\%): C, 51.33; H, 7.00; N, 7.48. Found: C, 51.30; H, 7.02; N, 7.53.

Methyl 1-acetyl-5-((2-methoxycarbonyl)ethoxy)pyrrolidine-2-carboxylate (7). Methyl acrylate $(0.12 \mathrm{~mL}, 1.35 \mathrm{mmol})$ was added to a solution of compound $1(50 \mathrm{mg}, 0.27 \mathrm{mmol})$ in dry THF $(5 \mathrm{~mL})$. Then, the reaction mixture was treated with ${ }^{t} \mathrm{BuOK}(27 \mu \mathrm{l}, 1 \mathrm{M}$ in THF) and stirred for $1 \mathrm{~h}$. Afterwards, $0.1 \mathrm{~N} \mathrm{HCl}(1 \mathrm{~mL})$ was added dropwise. The new mixture was diluted with EtOAc $(10 \mathrm{~mL})$, and washed with $\mathrm{H}_{2} \mathrm{O}(10 \mathrm{~mL})$. The organic phase was dried over anhydrous $\mathrm{Na}_{2} \mathrm{SO}_{4}$, filtered, and concentrated in vacuo to give a residue that was purified by silica gel column chromatography eluting with $\mathrm{MeOH} / \mathrm{EtOAc}$ (1:9) to afford compound 7 as a mixture of diastereomers (10 mg, 14\% yield). ${ }^{1} \mathrm{H}-\mathrm{NMR}\left(\mathrm{CDCl}_{3}\right): \delta 1.89-1.95\left(\mathrm{~m}, 1 \mathrm{H}, \mathrm{CH}_{2}\right), 2.01-$ 2.09 (m, $2 \mathrm{H}, \mathrm{CH}_{2}$ ), 2.16 (s, 3H, $\mathrm{CH}_{3}$ ), 2.26-2.33 (m, $\left.1 \mathrm{H}, \mathrm{CH}_{2}\right), 2.59$ (t, $2 \mathrm{H}, J=6.0 \mathrm{~Hz}, \mathrm{CH}_{2} \mathrm{CO}$ ), 3.66-3.73 (m, 8H, $\mathrm{CH}_{3} \mathrm{O}, \mathrm{CH}_{3} \mathrm{O}, \mathrm{CH}_{2} \mathrm{O}$ ), 4.53 (d, $\left.1 \mathrm{H}, J=8.9 \mathrm{~Hz}, \mathrm{CH}\right), 5.18$ (d, $1 \mathrm{H}, J=4.2 \mathrm{~Hz}$, $\mathrm{CH})$; ESI+ (m/z): $274.5(\mathrm{M}+\mathrm{H})^{+}$; Anal. Calcd. for $\mathrm{C}_{12} \mathrm{H}_{19} \mathrm{NO}_{6}$ (\%): C, 52.74; H, 7.01; N, 5.13. Found: C, 52.85; H, 7.03; N, 5.18.

(E)-Dimethyl 6-acetamidohept-2-enedioate (8). Trimethyl phosphonoacetate (77 $\mu$ l, 0.53 mmol) was added at $-30{ }^{\circ} \mathrm{C}$ to a solution of $60 \% \mathrm{NaH}(11 \mathrm{mg}, 0.53 \mathrm{mmol})$ in dry THF (5 mL). The reaction mixture was stirred at the same temperature for $45 \mathrm{~min}$ and a solution of compound 1 (50 mg, $0.27 \mathrm{mmol}$ ) in dry THF ( $5 \mathrm{~mL}$ ) was added dropwise. The new mixture was let reach to $25{ }^{\circ} \mathrm{C}$ and stirred for $17 \mathrm{~h}$ more. Afterwards, a $\mathrm{KH}_{2} \mathrm{PO}_{4}$ buffer solution $(5 \mathrm{~mL})(\mathrm{pH}=7)$ was added and the aqueous layer was washed with EtOAc $(3 \times 10 \mathrm{~mL})$. The combination of the organic phases was dried over anhydrous $\mathrm{Na}_{2} \mathrm{SO}_{4}$, filtered, and concentrated in vacuo. The residue obtained was purified by silica gel column chromatography eluting with hexane/EtOAc (1:4) to afford compound 8 as an oil (45 mg, 69\% yield). ${ }^{1} \mathrm{H}-\mathrm{NMR}\left(\mathrm{CDCl}_{3}\right): \delta 1.75$ (td, $1 \mathrm{H}, J=$ $\left.12.4 \mathrm{~Hz}, J=7.3 \mathrm{~Hz}, \mathrm{CH}_{2}\right), 1.93-2.01\left(\mathrm{~m}, 4 \mathrm{H}, \mathrm{COCH}_{3}, \mathrm{CH}_{2}\right), 2.15-2.23\left(\mathrm{~m}, 2 \mathrm{H}, \mathrm{CH}_{2}\right), 3.65(\mathrm{~s}$, $3 \mathrm{H}, \mathrm{CH}_{3} \mathrm{O}$ ), 3.69 (s, 3H, $\mathrm{CH}_{3} \mathrm{O}$ ), 4.58 (dd, $\left.1 \mathrm{H}, J=13.1 \mathrm{~Hz}, J=7.4 \mathrm{~Hz}, \mathrm{CH}\right), 5.78(\mathrm{~d}, 1 \mathrm{H}, J=15.5$ $\mathrm{Hz}, \mathrm{CH}=\underline{\mathrm{CHCO}}), 6.14(\mathrm{~d}, 1 \mathrm{H}, J=7.5 \mathrm{~Hz}, \mathrm{NH}), 6.85\left(\mathrm{~m}, 1 \mathrm{H}, \mathrm{CH}_{2} \mathrm{CH}=\mathrm{CH}\right) ;{ }^{13} \mathrm{C}-\mathrm{NMR}\left(\mathrm{CDCl}_{3}\right)$ : $23.1\left(\mathrm{COCH}_{3}\right)$, 27.9, $30.9\left(\mathrm{CH}_{2}, \mathrm{CH}_{2}\right)$, 51.4, 51.6, $52.5\left(\mathrm{CH}_{3} \mathrm{O}, \mathrm{CH}_{3} \mathrm{O}, \mathrm{CH}\right), 121.8(\mathrm{CH}=\underline{\mathrm{CHCO}})$, $147.1\left(\mathrm{CH}_{2} \underline{\mathrm{CH}}=\mathrm{CH}\right), 166.7,169.9,172.6(\mathrm{CO})$; ESI+ $(\mathrm{m} / \mathrm{z})$ : $244.4(\mathrm{M}+\mathrm{H})^{+}$; Anal. Calcd. for $\mathrm{C}_{11} \mathrm{H}_{17} \mathrm{NO}_{5}$ (\%): C, 54.31; H, 7.04; N, 5.76. Found: C, 54.35; H, 7.12; N, 5.79. 


\section{Acknowledgements}

We are grateful to the Ministerio de Educación y Ciencia (project CTQ2006-05825/BQU). M. P. -F. also thanks the Gobierno de La Rioja for her doctoral fellowship. F. R. thanks the C.S.I.C. for his JAE-Doc Program contract.

\section{References}

1. Krane, S. M. Amino Acids 2008, 35, 703.

2. (a) Friess, W., Ed., Collagen in drug delivery and tissue engineering In Adv. Drug Delivery Rev. 2003, 55, issue 12, pp 1529-1530. (b) Kotch, F. W.; Guzei, I. A.; Raines R. T. J. Am. Chem. Soc. 2008, 130, 2952.

3. (a) Agalar, F.; Hamaloglu, E.; Daphan, C.; Tarim, A.; Onur, R.; Renda, N.; Sayek, I. Aust. N.Z. J. Surg. 2000, 70, 739. (b) Eroglu, E.; Agalar, F.; Altuntas, I.; Eroglu, F. Tohoku J. Exp. Med. 2004, 204, 11.

4. (a) Chung, J. Y. L.; Wasicak, J. T.; Arnold, W. A.; May, C. S.; Nadzan, A. M.; Holladay, M. W. J. Org. Chem. 1990, 55, 270. (b) Sacchi, A.; de Caprariis, P.; Mayol, L.; De Martino, G. J. Heterocycl. Chem. 1995, 32, 1067.

5. (a) Manzoni, L.; Colombo, M.; May, E.; Scolastico, C. Tetrahedron 2001, 57, 249. (b) Belvisi, L.; Colombo, L.; Colombo, M.; Di Giacomo, M.; Manzoni, L.; Vodopivec, B.; Scolastico, C. Tetrahedron 2001, 57, 6463. (c) Belvisi, L.; Colombo, L.; Manzoni, L.; Potenza, D.; Scolastico, C. Synlett 2004, 1449. (d) Manzoni, L.; Arosio, D.; Belvisi, L.; Bracci, A.; Colombo, M.; Invernizzi, D.; Scolastico, C. J. Org. Chem. 2005, 70, 4124. (e) Cluzeau, J.; Lubell, W. D. Biopolymers 2005, 80, 98.

6. Chiesa, M. V.; Manzoni, L.; Scolastico, C. Synlett 1996, 441.

7. Olsen, R. K.; Ramasamy, K.; Emery, T. J. Org. Chem. 1984, 49, 3527.

8. Johannesson, P.; Lindeberg, G.; Tong, W.; Gogoll, A.; Synnergren, B.; Nyberg, F.; Karln, A.; Hallberg, A. J. Med. Chem. 1999, 42, 4524.

9. Rios, R.; Ibrahem, I.; Vesely, J.; Sundén, H.; Córdova, A. Tetrahedron Lett. 2007, 48, 8695.

10. Cabrera, S.; Reyes, E.; Alemán, J.; Milelli, A.; Kobbelgaard, S.; Jørgensen, K. A. J. Am. Chem. Soc. 2008, 130, 12031.

11. (a) Shono, T.; Matsumura, Y.; Tsubata, K.; Sugihara, Y.; Yamame, S. -I.; Kanazawa, T.; Aoki, T. J. Am. Chem. Soc. 1982, 104, 6697. (b) Shono, T.; Matsumura, Y.; Tsubata, K. Org. Synth. 1985, 63, 206.

12. (a) Lee-Ruff, E.; Mladenova, G. Chem. Rev. 2003, 103, 1449. (b) Namyslo, J. C.; Kaufmann, D. E. Chem. Rev. 2003, 103, 1485. (c) Pérez-Fernández, M.; Avenoza, A.; Busto, J. H.; Peregrina, J. M.; Rodríguez, F. Tetrahedron 2008, 64, 9088. 
13. (a) Balaji, V. N.; Ramnarayan, K.; Chan, M. F.; Rao, S. N. Pept. Res. 1995, 8, 178. (b) Gaoni, Y. Org. Prep. Proced. Int. 1995, 27, 185. (c) Palacin, S.; Chin, D. N.; Simanek, E. E.; MacDonald, J. C.; Whitesides, G. M.; McBride, M. T.; Palmore, G. T. R. J. Am. Chem. Soc. 1997, 119, 11807. (d) Yahalom, D.; Rahimipour, S.; Koch, Y.; Ben-Aroya, N.; Fridkin, M. J. Med. Chem. 2000, 43, 2831. (e) Volk, F. -J.; Wagner, M.; Frahm, A. W. Tetrahedron: Asymmetry 2003, 14, 497. (f) Truong, M.; Lecornué, F.; Fadel, A. Tetrahedron: Asymmetry 2003, 14, 1063. (g) Koch, C. -J; Höfner, G.; Polborn, K.; Wanner, K. T. Eur. J. Org. Chem. 2003, 2233. (h) Hazelard, D.; Fadel, A.; Girard, C. Tetrahedron: Asymmetry 2006, 17, 1457. (i) Gauzy, C.; Saby, B.; Pereira, E.; Faure, S.; Aitken, D. J. Synlett 2006, 1394.

14. (a) Allan, R. D.; Hanrahan, J. R.; Hambley, T. W.; Johnston, G. A. R.; Mewett, K. N.; Mitrovic, A. D. J. Med. Chem. 1990, 33, 2905 (b) Gaoni, Y.; Chapman, A. G.; Parvez, N.; Pook, P. C. -K.; Jane, D. E.; Watkins, J. C. J. Med. Chem. 1994, 37, 4288.

15. (a) Avenoza, A.; Busto, J. H.; Canal, N.; Peregrina, J. M. Chem. Commun. 2003, 1376. (b) Avenoza, A.; Busto, J. H.; Peregrina, J. M.; Pérez-Fernández, M. Tetrahedron 2005, 61, 4165. (c) Avenoza, A.; Busto, J. H.; Canal, N.; Peregrina, J. M.; Pérez-Fernández, M. Org. Lett. 2005, 7, 3597. (d) Avenoza, A.; Busto, J. H.; Canal, N.; Peregrina, J. M. J. Org. Chem. 2005, 70, 330. (e) Avenoza, A.; Busto, J. H.; Mata, L.; Peregrina, J. M.; Pérez-Fernández, M. Synthesis 2008, 743.

16. Avenoza, A.; Busto, J. H.; Canal, N.; García, J. I.; Jiménez-Osés, G.; Peregrina, J. M.; PérezFernández, M. New J. Chem. 2007, 31, 224.

17. (a) Boutagy, J.; Thomas, R. Chem. Rev. 1974, 74, 87. (b) Buss, A. D.; Warren, S. Tetrahedron Lett. 1983, 24, 3931.

18. Verma, S. K.; Atanes, M. N.; Busto, J. H.; Thai, D. L.; Rapoport, H. J. Org. Chem. 2002, 67, 1314. 